\title{
Vitamin D deficiency in healthy children in Bahrain: do gender and age matter?
}

Hasan Isa, ${ }^{1}$ Mohamed Almaliki, ${ }^{2}$ Aysha Alsabea ${ }^{3}$ and Afaf Mohamed ${ }^{4}$

${ }^{1}$ Department of Paediatrics, Arabian Gulf University, Manama, Bahrain. ${ }^{2}$ Department of Paediatrics, Al-Kindi Specialised Hospital, Manama, Bahrain. ${ }^{3}$ Department of Paediatrics, Salmaniya Medical Complex, Manama, Bahrain. ${ }^{4}$ Shaikh Jaber Alsabah Health Centre, Manama, Bahrain. (Correspondence to: Hasan Isa: halfaraj@hotmail.com).

\begin{abstract}
Background: Vitamin D deficiency is a global health problem in children. The vitamin D status of children and adolescents has not been evaluated in Bahrain.

Aims: This cross-sectional study aimed to determine the prevalence of vitamin D deficiency in healthy children in Bahrain and to investigate the relationship between vitamin $\mathrm{D}$ level and age and sex.

Methods: Medical records of children aged 1 month to 16 years who attended a vitamin D screening campaign at Al Kindi Specialized Hospital, Bahrain between September and October 2016 were reviewed. Data on sex and age were recorded and vitamin D level was measured as serum 25-hydroxyvitamin D [25(OH)D]. Children were grouped as: vitamin D sufficient $[25(\mathrm{OH}) \mathrm{D} \geq 75 \mathrm{nmol} / \mathrm{L}]$, vitamin D insufficient (51-74 $\mathrm{nmol} / \mathrm{L}$ ) and vitamin D deficient ( $\leq 50 \mathrm{nmol} / \mathrm{L}$ ).

Results: A total of 531 children were included in the study, 50.8\% of whom were boys. Most of the children (93.4\%) had low vitamin D levels; 78.3\% were vitamin D deficient and 15.1\% vitamin D insufficient. Only 6.6\% were vitamin D sufficient. A significantly greater proportion of girls were vitamin $\mathrm{D}$ deficient than boys $(P<0.001)$. More primary-school children and adolescents were vitamin $\mathrm{D}$ deficient than preschool children $(P<0.001)$. A negative correlation was found between vitamin D level and age $(r=-0.467 ; \mathrm{P}<0.001)$. Regression analysis showed that vitamin $\mathrm{D}$ level decreased by $-2.164 \mathrm{nmol} / \mathrm{L}$ for each year of age.

Conclusion: Vitamin D deficiency is a problem among healthy children in Bahrain. Public health policies or interventions are suggested to improve vitamin D status in Bahrain, especially for school-aged children.

Keywords: vitamin D deficiency, child, adolescent, prevalence, Bahrain

Citation: Isa H; Almaliki M; Alsabea A; Mohamed A. Vitamin D deficiency in healthy children in Bahrain: do gender and age matter? East Mediterr

Health J. 2020;26(3):260-267. https://doi.org/10.26719/emhj.19.084

Received: 16/01/18; accepted: 04/06/18

Copyright (C) World Health Organization (WHO) 2020. Open Access. Some rights reserved. This work is available under the CC BY-NC-SA 3.0 IGO license (https://creativecommons.org/licenses/by-nc-sa/3.o/igo).
\end{abstract}

\section{Introduction}

Vitamin D is a vital steroid hormone (1). It is mainly produced in the skin after exposure to sunlight $(1-3)$. If sun exposure is inadequate, vitamin $\mathrm{D}$ level can be maintained by taking supplements or foods that contain vitamin D (2). However, food sources of vitamin D are few $(1,3)$.

Vitamin D has a crucial role in improving physiological function in both skeletal and extraskeletal tissues $(1,2)$. It is essential for intestinal calcium absorption, homeostasis and bone mineralization, especially during infancy, childhood and puberty $(1,2,4)$. Only $10-15 \%$ of dietary calcium is absorbed without vitamin D (1). Serum 25-hydroxyvitamin D [25(OH)D] levels less than $50 \mathrm{nmol} / \mathrm{L}$ can lead to a marked decrease in intestinal calcium absorption (1). This is associated with increased parathyroid hormone secretion and decreased insulinlike growth factor 1 (1). Serum $25(\mathrm{OH}) \mathrm{D}$ level is directly connected to bone mineral density with a maximum density attained when the $25(\mathrm{OH}) \mathrm{D}$ level is $\geq 100 \mathrm{nmol} / \mathrm{L}$ (1). Severe vitamin D deficiency impairs bone mineralization leading to osteomalacia and rickets (2). Recent evidence shows that the role of vitamin $\mathrm{D}$ goes beyond calcium and phosphorous metabolism (3). Many extra skeletal illnesses have been associated with vitamin D deficiency, such as those related to fuel metabolism, the cardiovascular system, cancer and the immune system $(1,3)$.

Despite several preventive approaches, vitamin D deficiency has remained a global health problem in children $(2,3,5)$. Vitamin D status in children has been evaluated in many countries (1-11). In Bahrain, two published studies on vitamin D status looked at neonatal and adult age groups $(12,13)$. To our knowledge, the vitamin $\mathrm{D}$ status of children and adolescents has not been evaluated in Bahrain.

This study aimed to determine the prevalence of vitamin $\mathrm{D}$ deficiency in a large sample of healthy children and adolescents in Bahrain, evaluate any sex and age differences between children with low vitamin $\mathrm{D}$ levels and those with adequate vitamin $\mathrm{D}$, and correlate vitamin D levels with children's age.

\section{Methods}

\section{Study design and sample}

This was a cross-sectional study in which the medical records of 593 healthy children who attended the vitamin 
D screening campaign at Al-Kindi Specialized Hospital, Bahrain between 27 September and 1 October 2016 were reviewed. The vitamin D screening campaign is a free campaign organized by Al-Kindi Specialized Hospital, a private hospital in Manama, the capital of Bahrain, as part of their social commitments to the community. This campaign is considered a national campaign as all healthy children in Bahrain were invited. The campaign was conducted in the clinics of the paediatrics department. Children were triaged by nursing staff before enrolment for blood collection. Children with any illness were excluded in this campaign. Children were also excluded from the study if they were under one month of age or more than 16 years, and if data were missing on their health condition or serum $25(\mathrm{OH}) \mathrm{D}$ levels.

\section{Data collection}

Data on sex, age at attending the campaign and serum 25(OH)D level were collected. Age was divided into three groups: 1 month to 5 years (preschool), 6 to 10 years (school age) and 11 to 16 years (adolescent). Two millilitres of venous blood were collected from each child by trained nurses and kept in a plain tube as vitamin $\mathrm{D}$ test is dependent on the serum level so this type of tube should be used and not an ethylenediaminetetraacetic acid (EDTA) tube. The serum was separated from the whole blood and vitamin D levels were measured using an Elecsys vitamin D total assay (Roche Cobas E 411 analyser apparatus, Switzerland). Vitamin D status was based on serum 25(OH)D level and categorized into three groups: vitamin $\mathrm{D}$ deficient [serum $25(\mathrm{OH}) \mathrm{D} \leq 50$ $\mathrm{nmol} / \mathrm{L}]$, vitamin D insufficient ( $51-74 \mathrm{nmol} / \mathrm{L})$ and vitamin D sufficient $\geq 75 \mathrm{nmol} / \mathrm{L})(14,15)$.

\section{Statistical analysis}

Data were analysed using SPSS, version 21. Frequencies and percentages for sex, age group and vitamin D group were calculated. Fisher exact and Pearson chi-squared tests were used to compare categorical variables (sex, age groups and vitamin D groups). Continuous variables (children's age and vitamin D levels) were checked for normal distribution using the Kolmogorov-Smirnov test. Group data are presented as a mean and standard deviation (SD) or median and range. Vitamin D groups were compared using the Mann-Whitney U and KruskalWallis tests. Spearman's correlation coefficient $\left(r_{s}\right)$ was used to examine correlations between vitamin $\mathrm{D}$ level and the children's age. Coefficient of determination $\left(r^{2}\right)$ and the simple regression equation were calculated. A $P$-value $<0.05$ was considered statically significant.

\section{Ethical considerations}

Informed consent was obtained from the parents before the blood test. Patients with vitamin D deficiency were offered a free consultation with a paediatrician to discuss the result of the test and they were advised to be treated with the appropriate doses of vitamin D therapy. This study was approved by the secondary care medical research subcommittee of Al-Kindi Specialised Hospital, Bahrain, and was conducted in accordance with the principles of Helsinki Declaration.

\section{Results}

A total of 593 healthy children were tested for serum 25(OH)D level. The children came only for vitamin D screening and they were not seeking any medical consultation. Sixty-two (10.4\%) children were excluded because they had no laboratory results because their blood samples were inadequate. No sick patient came for the screening; therefore no children were excluded based on the health condition. Clinical characteristics and laboratory results of the remaining 531 children are shown in Table 1. Of the 531 children, 270 (50.8\%) were boys. Most of the children (93.4\%) had low vitamin D levels; only $6.6 \%$ had an adequate vitamin D level. Mean serum 25(OH)D level was significantly lower in girls [37.4 (SD 19.9) nmol/L] than boys [43.4 (SD 22.4) nmol/L] $(P<0.001)$. Mean vitamin $\mathrm{D}$ levels for preschool children, primary-school children and adolescents were 47.4 (SD 22.4) nmol/L, 37.4 $(\mathrm{SD} 17.47) \mathrm{nmol} / \mathrm{L}$ and 27.45 (SD 17.47) nmol/L respectively $(P<0.001)$.

Table 2 shows the demographic characteristics of the children categorized according to vitamin $\mathrm{D}$ level (sufficient and low). A greater proportion of girls (94.3\%) had low vitamin D compared with boys (92.6\%), but this was not statistically significant $(P=0.487)$. The mean and median ages of the children with low vitamin $\mathrm{D}$ were significantly higher than those of children with adequate vitamin $\mathrm{D}$ levels $(P<0.001)$. A significantly greater proportion of primary-school children and adolescents had low vitamin $\mathrm{D}$ compared to preschool children $(P=$ 0.015). Only two infants were under one year (six months and eight months); one had vitamin D deficiency (40.7 $\mathrm{nmol} / \mathrm{L})$ and the other had insufficient vitamin D (64.4 $\mathrm{nmol} / \mathrm{L})$.

The association between vitamin D group (vitamin D sufficient, vitamin D insufficient and vitamin D deficient)

\begin{tabular}{|c|c|}
\hline \multicolumn{2}{|c|}{$\begin{array}{l}\text { Table } 1 \text { Demographic characteristics and vitamin D levels of } \\
\text { the children }(n=531)\end{array}$} \\
\hline Variable & Value \\
\hline \multicolumn{2}{|l|}{ Sex [no. (\%)] } \\
\hline Male & $270(50.8)$ \\
\hline Female & $261(49.2)$ \\
\hline Age in years [median (range)] & $6(0.53-16)$ \\
\hline \multicolumn{2}{|l|}{ Age group [no. (\%)] } \\
\hline 1 month -5 years & $257(48.4)$ \\
\hline $6-10$ years & $185(34.8)$ \\
\hline $11-16$ years & $89(16.8)$ \\
\hline \multicolumn{2}{|l|}{ Vitamin D level (nmol/L) } \\
\hline Median (range) & $36.4(7.5-175)$ \\
\hline Mean (SD) & $39.8(21.5)$ \\
\hline \multicolumn{2}{|l|}{ Vitamin D level (nmol/L) [no. (\%)] } \\
\hline$\geq 75$ (sufficient) & $35(6.6)$ \\
\hline 51-74 (insufficient) & $80(15.1)$ \\
\hline$\leq 50$ (deficient) & $416(78.3)$ \\
\hline
\end{tabular}




\begin{tabular}{|c|c|c|c|c|}
\hline \multirow[t]{2}{*}{ Characteristic } & \multicolumn{2}{|c|}{ Vitamin D level } & \multirow[t]{2}{*}{ Total $(\mathrm{n}=531)$} & \multirow[t]{2}{*}{ P-value } \\
\hline & Sufficient $^{\mathrm{a}}(\mathrm{n}=35)$ & $\operatorname{Low}^{b}(n=496)$ & & \\
\hline \multicolumn{5}{|l|}{$\operatorname{Sex}[$ no. $(\%)]$} \\
\hline Male & $20(7.4)$ & $250(92.6)$ & 270 & \multirow[t]{2}{*}{0.487} \\
\hline Female & $15(5.7)$ & $246(94.3)$ & 261 & \\
\hline \multicolumn{5}{|l|}{ Age (years) } \\
\hline Mean (SD) & $4.04(3.5)$ & $6.44(3.7)$ & - & $<0.001$ \\
\hline Median (range) & $2.0(1.3-15)$ & $6.0(0.5-16)$ & - & $<0.001$ \\
\hline \multicolumn{5}{|l|}{ Age group [no. (\%)] } \\
\hline 1 month -5 years & $25(9.7)$ & $232(90.3)$ & 257 & \multirow[t]{3}{*}{0.015} \\
\hline $6-10$ years & $8.0(4.3)$ & 177 (95.7) & 185 & \\
\hline $11-16$ years & $2.0(2.2)$ & $87(97.8)$ & 89 & \\
\hline
\end{tabular}

SD: standard deviation.

and sex and age is shown in Table 3. Significantly more girls were vitamin $\mathrm{D}$ deficient than boys $(P<0.001)$. In addition, significantly greater proportions of primaryschool children and adolescents were vitamin $\mathrm{D}$ deficient compared with preschool children $(P<0.001)$.

The Spearman correlation coefficient test showed a moderate but statistically significant negative correlation between vitamin D level and children's age ( $r=-0.467 ; P<0.001)$. The coefficient of determination $\left(r^{2}\right)$ was -0.934 meaning that $93.4 \%$ of the variance in vitamin D level was explained by children's age. A simple linear regression was calculated to predict children's vitamin D levels as an outcome variable based on their age as the predictor variable (Figure 1). A significant regression equation was found: $F(1,529)=96.660 ; P<$ 0.001; $R^{2}=0.154$. Children's predicted vitamin $\mathrm{D}$ level is equal to-2.164(Age) nmol/L + 21.592, when age is measured in years. Children's average vitamin D level decreased by-2.164 nmol/L for each year of age.

\section{Discussion}

Our study showed a very high prevalence (93.4\%) of low vitamin D levels in healthy children in Bahrain. Prevalence of vitamin $\mathrm{D}$ deficiency in neighbouring countries and worldwide is shown in Table $4(1,3-10,12,13,16-21)$. The available evidence suggests that vitamin $\mathrm{D}$ deficiency is an important child health problem worldwide (1-13,16-21). Studies on vitamin D deficiency in child and adult populations across Europe show an overall prevalence of $13 \%$ (7260/55 844) (22). In a large, population-based Dutch cohort, $30 \%(1250 / 4167)$ of the children were deficient in vitamin $\mathrm{D}(<50 \mathrm{nmol} / \mathrm{L})$ and $66 \%(2750 / 4167)$ had insufficient vitamin $\mathrm{D}(<75 \mathrm{nmol} / \mathrm{L})$ (9). A study in the United States of America (USA) showed a higher prevalence of vitamin D deficiency of $40 \%$ (146/365) in healthy infants and toddlers (21). The first national estimate of rickets caused by vitamin $\mathrm{D}$ deficiency in Australia gave an incidence of 4.9/100 ooo population a year in children $\leq 15$ years (5).

\begin{tabular}{|c|c|c|c|c|c|}
\hline \multirow[t]{2}{*}{ Variable } & \multicolumn{3}{|c|}{ Vitamin D group } & \multirow[t]{2}{*}{ Total } & \multirow[t]{2}{*}{ P-value } \\
\hline & Sufficient $^{\mathrm{a}}(\mathrm{n}=\mathbf{3 5})$ & Insufficient $^{\mathrm{b}}(\mathrm{n}=\mathbf{8 0})$ & Deficient $^{c}(n=416)$ & & \\
\hline \multicolumn{6}{|l|}{$\operatorname{Sex}[$ no. $(\%)]$} \\
\hline Male & $20(7.4)$ & $45(16.7$ & $205(75.9)$ & 270 & \multirow{2}{*}{$<0.001$} \\
\hline Female & $15(5.7)$ & $35(13.4)$ & $211(80.8)$ & 261 & \\
\hline \multicolumn{6}{|l|}{ Age (years) } \\
\hline Mean (SD) & $4.04(3.5)$ & $4.47(3.26)$ & $6.82(3.7)$ & - & $<0.001$ \\
\hline Median (range) & $2.0(1.3-15.0)$ & $3.0(0.65-15)$ & $6.0(0.53-16)$ & - & $<0.001$ \\
\hline \multicolumn{6}{|l|}{ Age group [no. (\%)] } \\
\hline 1 month -5 years & $25(9.7)$ & $59(23)$ & $173(67.3)$ & 257 & \multirow{3}{*}{$<0.001$} \\
\hline $6-10$ years & $8(4.3)$ & $15(8.1)$ & $162(87.6)$ & 185 & \\
\hline $11-16$ years & $2.0(2.2)$ & $6.0(6.7)$ & $81(91.0)$ & 89 & \\
\hline
\end{tabular}

SD: standard deviation.

${ }^{a}$ Serum 25(OH)D $\geq 75 \mathrm{nmol} / \mathrm{L}$.

${ }^{b} \operatorname{Serum} 25(\mathrm{OH}) \mathrm{D}=\mathrm{mL} 51-74 \mathrm{nmol} / \mathrm{L}$.

Serum $25(\mathrm{OH}) \mathrm{D} \leq 50 \mathrm{nmol} / \mathrm{L}$.

${ }^{d}$ Kruskal-Wallis test was used to compare differences for continuous variables and the Pearson chi-squared was used for categorical variables. 


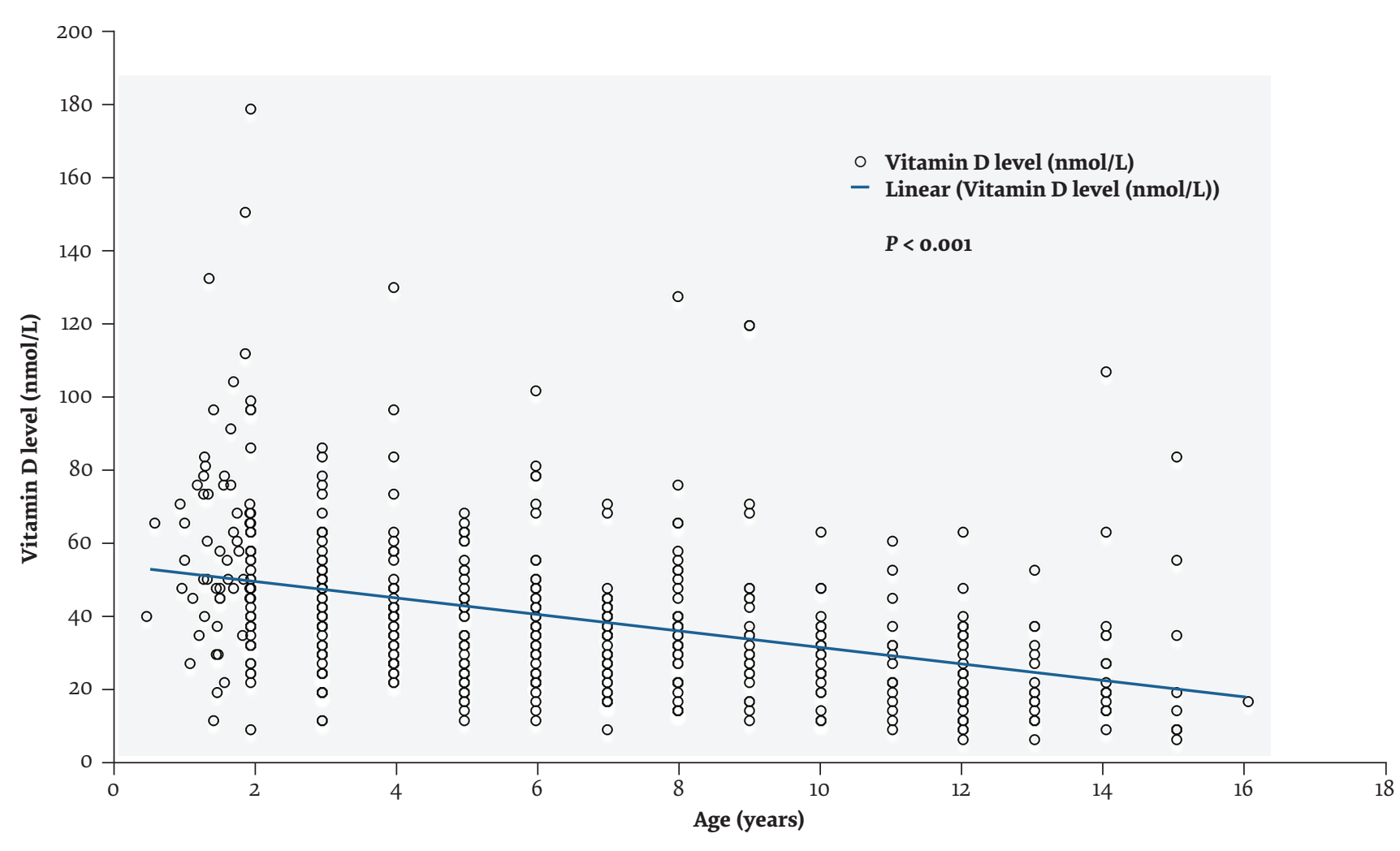

Figure 1 Relationship between vitamin D level and age in healthy children in Bahrain $(n=531)$

Rickets caused by vitamin D deficiency has almost been eradicated in Western Europe and North America $(1,23)$. However, the prevalence of vitamin D deficiency and rickets remains unacceptably high in Asia, Africa and the Middle East (1). Compared with neighbouring countries, our study showed an almost similar prevalence of vitamin D deficiency in children $(78.3 \%)$ as that reported in Oman (69.1\%) (217/314), Kuwait (77\%) (158/204) and Qatar (68.8\%) (315/458) (16-18). However, the prevalence of vitamin D deficiency in our study was higher than that reported in Saudi Arabia (45.5\%, 960/2110) (1). Similar to our study, a study from Fars Province, southern Islamic Republic of Iran, reported a very high prevalence of vitamin D deficiency of $81 \%$ (388/477) in children aged 9 to 18 years (7). A Korean study of children aged 6 to12 years found that 59\% (195/330) had vitamin D deficiency (6) and a study in Turkey found a prevalence of $40 \%(176 / 440)$ of poor vitamin D status among Turkish children aged $0-16$ years (8).

As well as high prevalence of vitamin D deficiency, $15.1 \%$ of the children and adolescents in our study had insufficient vitamin $\mathrm{D}$ (serum 25(OH)D $=52.4-72.4$ $\mathrm{nmol} / \mathrm{L})$. Similarly, vitamin D deficiency ranged between $23 \%(49 / 209)$ at the end of summer and $80 \%(225 / 280)$ at the end of winter and vitamin D insufficiency between $12 \%(33 / 280)$ at the end of winter and $28 \%(58 / 209)$ at the end of summer in children in Ankara, Turkey (4). In a large cross-sectional study in Wuxi (southern China) among 5571 young children aged 1 to 3 years, vitamin D deficiency) (serum $25(\mathrm{OH}) \mathrm{D}<50 \mathrm{nmol} / \mathrm{L}$ ) was found in only $897(16 \%)(19)$. However, the number increased to $3058(55 \%)$ when a higher cut-off for sufficient vitamin D level was considered ( $\geq 75 \mathrm{nmol} / \mathrm{L}$ ) (19). Another study in China on 6008 children aged 1 month to 16 years showed a lower prevalence of vitamin $D$ deficiency compared with vitamin D insufficiency (20). In Saudi Arabia, vitamin $\mathrm{D}$ deficiency and insufficiency were almost equal in children and adolescents between 6 and 15 years of age, $45.5 \%(960 / 2110)$ and $49.9 \%$ (1053/2110) respectively (1).

In our study, we focused on the role of sex and age of healthy children on the development of vitamin $\mathrm{D}$ deficiency. However, other factors can play a role in the increase of vitamin D deficiency, such as low vitamin D intake and low sunshine exposure $(2,4,7,8,11)$. Moreover, breastfeeding, skin pigmentation, covering the skin, ethnicity, season, low physical activity and high fat mass index can lead to low vitamin D levels $(2,7-9,16)$. Although Bahrain is not affected by long winters, factors such indoor lifestyle, avoidance of exposure to sunlight, environmental pollution and the scarce dietary sources of vitamin $\mathrm{D}$ should be considered in relation to the high levels of vitamin D deficiency we found (3). However, an American study in 2008 found that skin pigmentation, sun exposure, time spent outdoors and sunscreen use were not predictors of $25(\mathrm{OH}) \mathrm{D}$ concentration or vitamin D deficiency, as was hypothesized (21). However, a recent study published in 2015 from the Islamic Republic of Iran showed that vitamin D concentration was associated with sun exposure, physical activity, age and pubertal status (7). Moreover, darker skin, limited sun exposure, 


\begin{tabular}{|c|c|c|c|c|c|c|c|}
\hline $\begin{array}{l}\text { Country } \\
\text { (reference) }\end{array}$ & $\begin{array}{l}\text { Total no. } \\
\text { of healthy } \\
\text { subjects }\end{array}$ & Age $^{a}$ & $\begin{array}{l}\text { Low } \\
\text { vitamin D } \\
(\%)\end{array}$ & $\begin{array}{c}\text { Vitamin D } \\
\text { insufficiency } \\
(\%)\end{array}$ & $\begin{array}{l}\text { Vitamin D } \\
\text { deficiency } \\
(\%)\end{array}$ & $\begin{array}{c}\text { Sex } \\
\text { difference }\end{array}$ & Age differences \\
\hline Bahrain (12) & 403 & Newborns & 90.3 & 37.5 & 52.9 & - & - \\
\hline Bahrain $^{\mathrm{b}}$ & 531 & $\begin{array}{l}1 \text { month } \\
-16 \text { years }\end{array}$ & 93.4 & 15.1 & 78.3 & NS & Negative correlation \\
\hline Bahrain (13) & 500 & Adults & 86.4 & 37 & 49.4 & $\mathrm{~F}>\mathrm{M}$ & Positive correlation \\
\hline Kuwait (16) & 204 & 9 (SD 2.7) & 92 & 14 & 77 & - & - \\
\hline Oman (17) & 314 & $9-10$ & 96.5 & 27.4 & 69.1 & $\mathrm{~F}>\mathrm{M}$ & - \\
\hline Qatar (18) & 458 & $<16$ & 68.8 & - & - & $\mathrm{F}>\mathrm{M}$ & $\begin{array}{l}\text { More older children had } \\
\text { vitamin D deficiency than } \\
\text { younger children }\end{array}$ \\
\hline Saudi Arabia (1) & 2110 & $6-15$ & $95 \cdot 3$ & 49.9 & 45.5 & $\mathrm{~F}>\mathrm{M}$ & $\begin{array}{l}\text { More older children had } \\
\text { vitamin D deficiency than } \\
\text { younger children }\end{array}$ \\
\hline $\operatorname{Iran}(\mathrm{IR})(7)$ & 477 & $9-18$ & 96 & 15 & 81 & NS & $\begin{array}{l}\text { More older children had } \\
\text { vitamin } D \text { deficiency than } \\
\text { younger children }\end{array}$ \\
\hline Turkey (4) & 280 & $3-17$ & $12-80$ & $12-28$ & $23-80$ & NS & Negative correlation \\
\hline Turkey (8) & 440 & $0-16$ & 40 & 15 & 25 & $\mathrm{~F}>\mathrm{M}$ & Negative correlation \\
\hline China (19) & 5571 & $1-3$ & 16.1 & - & 16.1 & NS & More in older age \\
\hline China (20) & 6008 & $\begin{array}{l}1 \text { month } \\
-16 \text { years }\end{array}$ & $32-94$ & $32-94$ & $5-57$ & NS & More in older age \\
\hline Korea (6) & 330 & $6-12$ & 59.1 & - & - & NS & NS \\
\hline Netherlands (9) & 4167 & $5.7-8$ & 29.8 & - & 29.8 & NS & $\begin{array}{c}\text { More older children had } \\
\text { vitamin D deficiency than } \\
\text { younger children }\end{array}$ \\
\hline Canada (10) & 5306 & $6-79$ & 5.4 & - & 5.4 & $\mathrm{M}>\mathrm{F}$ & - \\
\hline Mexico (3) & 1025 & $2-12$ & $28-55$ & $18-30$ & $10-25$ & NS & Preschool > school age \\
\hline USA (21) & 380 & $\begin{array}{l}8 \text { months } \\
-2 \text { years }\end{array}$ & 54 & 40 & 14 & NS & - \\
\hline Australia (5) & 851 & $\leq 15$ & 47.7 & 91 & 9.0 & $\mathrm{M}>\mathrm{F}$ & $\begin{array}{l}\text { More older children had } \\
\text { vitamin D deficiency than } \\
\text { younger children }\end{array}$ \\
\hline
\end{tabular}

UAE: United Arab Emirates; IR: Islamic Republic of; USA: United States of America; F: female; M: male; NS: no significant difference. 
less time spent outdoors, low physical activity and low dietary sources of vitamin $\mathrm{D}$ were also shown to reduce vitamin D concentration in other studies $(2,9,18)$.

In our study, no significant differences were found between boys and girls in the overall occurrence of low vitamin D. However, a significantly greater proportion of girls were in the vitamin D deficiency group, and the mean serum vitamin D level was significantly lower in girls than boys. In China, no significant difference was found between males and females in vitamin $\mathrm{D}$ levels even though females had lower mean levels (47.92, SD $16.47 \mathrm{nmol} / \mathrm{L}$ ) compared with males (53.4, SD $16.97 \mathrm{nmol} / \mathrm{L})$ (20). In contrast, the Saudi Arabian study reported a significantly higher prevalence of vitamin D deficiency in $97.8 \%$ (1073/1097) of females compared with $92.8 \%(940 / 101)$ of males $(P<0.001)(1)$. This finding may be due to less sun exposure of females because of limited outdoor activities, conservative clothing and the use of sunscreen products for cosmetic reasons (1). Similarly, the study in Turkey found that vitamin D deficiency was higher in females at the end of summer (4). However, no significant relationship was found between sex and vitamin D level at the end of winter (4).

Our work showed a negative correlation between vitamin D level and children's age. Similarly, the Iranian study showed that children's age was inversely associated with vitamin D concentration even after adjustment for physical activity, puberty stage, sun exposure and fat mass index (7). The Turkish study also reported a negative correlation between age and vitamin D levels (4); the frequency of vitamin $\mathrm{D}$ deficiency increased with age and was highest in adolescents and older age groups (4). We found that a significantly greater proportion of primaryschool children and adolescents were in the overall low vitamin $\mathrm{D}$ group and vitamin $\mathrm{D}$ deficiency group than preschool children. This finding is similar to studies in China, the Netherlands and Turkey $(8,9,20)$. In Europe, vitamin $\mathrm{D}$ levels varied considerably depending on age group (22). On the other hand, studies in Korea, Unite Arab Emirates and the USA found no significant difference in age between children with vitamin $\mathrm{D}$ deficiency and those with vitamin D insufficiency $(6,11,21)$. Further work is still needed to clarify if the vitamin D levels are really affected by children's age. If this is the case, more studies are required to investigate the reasons for the decline in vitamin D levels in older children.

All the participants in our study were apparently healthy children. Children's vitamin D status is not typically assessed as part of routine care (21). In fact, most people with vitamin $\mathrm{D}$ deficiency are asymptomatic or may present with vague and non-specific symptoms (1,21). These symptoms include muscle cramps, pain in weight-bearing joints, difficulty in walking, facial twitches and carpopedal spasms and may go unobserved for a long time (1,4). During childhood, clinical symptoms of vitamin D deficiency include hypocalcaemic seizures, lower-limb deformities, fractures, abnormal dentition and delayed developmental milestones (2). If vitamin $\mathrm{D}$ deficiency is severe and/or prolonged, linear growth impairment and many skeletal disorders may develop (1). However, obvious rickets and osteomalacia are only the tip of the iceberg in patients with severe vitamin D deficiency (1). Vitamin D deficiency has been shown to be associated with diseases related to: insulin production such as diabetes mellitus, hypertension, cancer and the immune system $(3,15,16)$. Even active rickets may not be identified on physical examination (4).

Most of the studies we reviewed used serum $25(\mathrm{OH})$ $\mathrm{D}$ level as a measure of vitamin D status in children (1,313,16-22) as we did. However, the cut-off points to decide vitamin $\mathrm{D}$ insufficiency and vitamin $\mathrm{D}$ deficiency are variable. Unlike our study where vitamin D levels of 50$74 \mathrm{nmol} / \mathrm{L}$ and $\leq 50 \mathrm{nmol} / \mathrm{L}$ were considered as vitamin $\mathrm{D}$ insufficiency and vitamin $\mathrm{D}$ deficiency respectively, the American Pediatric Endocrine Association recommends levels of $37.4-50 \mathrm{nmol} / \mathrm{L}$ as vitamin $\mathrm{D}$ insufficiency and $<37.4 \mathrm{nmol} / \mathrm{L}$ as vitamin D deficiency (24). It is important to use standardized serum 25(OH)D data in the assessment of the prevalence of vitamin $\mathrm{D}$ deficiency (20). In the Chinese study in Hangzhou, if the vitamin $\mathrm{D}$ deficiency threshold was changed to $<75 \mathrm{nmol} / \mathrm{L}$, almost all children had low vitamin D levels (20). It is generally agreed that no individuals in the population should have a $25(\mathrm{OH}) \mathrm{D}$ concentration $<25-30 \mathrm{nmol} / \mathrm{L}$ (22). In Europe, after standardization of serum 25(OH)D data, the prevalence vitamin $\mathrm{D}$ deficiency was revised upwards and downwards in some studies (22). However, standardization has very little effect on $25(\mathrm{OH}) \mathrm{D}$ data if the population samples are small (22).

Our study has some limitations. The prevalence of vitamin $\mathrm{D}$ deficiency was determined using a sample of children presenting to one hospital so the results may not be representative of the whole population of Bahrain. A nationwide study would give a more accurate reflection of the true prevalence. Another limitation is that other factors affecting vitamin D levels were not reviewed, such as sun exposure, indoor life style, clothing, dietary intake of vitamin $\mathrm{D}$, seasonal variation and environmental pollution.

Despite the limitations, our study is the first attempt to investigate vitamin D status among children aged 1 month to 16 years in Bahrain. The key strength was the inclusion of large number of healthy children with a wide range of ages. Our results suggest that paediatricians should have a higher degree of clinical suspicion for vitamin D deficiency and should screen all children with non-specific musculoskeletal pain. Moreover, the study provides further evidence to support public health policies or interventions to improve vitamin D status in Bahrain, especially for school-aged children as a targeted population.

\section{Conclusion}

Vitamin D deficiency is a very common problem among healthy children aged 1 to 16 years in Bahrain. Girls were more affected than boys and age was negatively correlated with vitamin D level. Further studies are needed: to calculate the prevalence of vitamin $\mathrm{D}$ deficiency in children sampled on a population basis; to evaluate the relationship between vitamin $\mathrm{D}$ level and other risk factors; 
to determine whether vitamin $\mathrm{D}$ deficiency during childhood affects later health; and to recommend preventive and therapeutic practices to avoid the long-term complications of such a hidden medical problem.

Funding: This study was not financially supported by any company or institute. However, the supply of vitamin D screening kits was sponsored by The Bahrain Financial Company. This company was not involved in the interpretation of the results of the tests or in this study.

Competing interests: None declared.

\section{Carence en vitamine $\mathrm{D}$ chez les enfants en bonne santé à Bahreïn : le sexe et l'âge ont-ils une importance?}

\section{Résumé}

Contexte : La carence en vitamine D est un problème de santé mondial chez l'enfant. Le bilan vitaminique D des enfants et des adolescents n'a pas été évalué à Bahreïn.

Objectifs : La présente étude transversale visait à déterminer la prévalence de la carence en vitamine D chez les enfants en bonne santé à Bahreïn afin d'examiner le rapport entre le taux de vitamine $\mathrm{D}$ et l'âge et le sexe.

Méthodes : Les dossiers médicaux d'enfants âgés d'un mois à 16 ans ayant participé à une campagne de dépistage de la carence en vitamine D à l'Hôpital spécialisé d'Al-Kindi (Bahreïn) entre septembre et octobre 2016 ont été passés en revue. Les données sur l'âge et le sexe ont été consignées et le taux de vitamine $\mathrm{D}$ a été évalué en mesurant la concentration de 25-hydroxyvitamine $\mathrm{D}$ sérique $[25(\mathrm{OH}) \mathrm{D}]$. Les enfants ont été répartis en trois groupes : taux de vitamine $\mathrm{D}$ suffisant [25(OH)D $\geq 75 \mathrm{nmol} / \mathrm{l}]$, taux de vitamine D insuffisant (51-74 nmol/l) et carence en vitamine $\mathrm{D}(\leq 50 \mathrm{nmol} / \mathrm{l})$.

Résultats : Au total, 531 enfants ont été inclus dans l'étude, dont 50,8\% de garçons. La plupart des enfants (93,4\%) présentaient un faible taux de vitamine D : 78,3\% présentaient une carence en vitamine D et $15,1 \%$ un taux de vitamine D insuffisant ; seuls 6,6 \% avaient un taux de vitamine D suffisant. Les filles étaient considérablement plus nombreuses que les garçons à présenter une carence en vitamine $\mathrm{D}(p<0,001)$. Les écoliers du cycle primaire et les adolescents étaient aussi plus nombreux que les enfants d'âge préscolaire à présenter une telle carence $(p<0,001)$. Une corrélation négative a été établie entre le taux de vitamine $\mathrm{D}$ et l'âge $(\mathrm{r}=-0,467 ; p<0,001)$. L'analyse de régression a montré que le taux de vitamine $\mathrm{D}$ diminuait de $-2,164 \mathrm{nmol} / \mathrm{l}$ pour chaque année d'âge.

Conclusion : La carence en vitamine D est un problème touchant les enfants en bonne santé à Bahreïn. Les politiques et les interventions de santé publique pourraient améliorer le bilan vitaminique D à Bahreïn, en particulier pour les enfants d'âge scolaire.

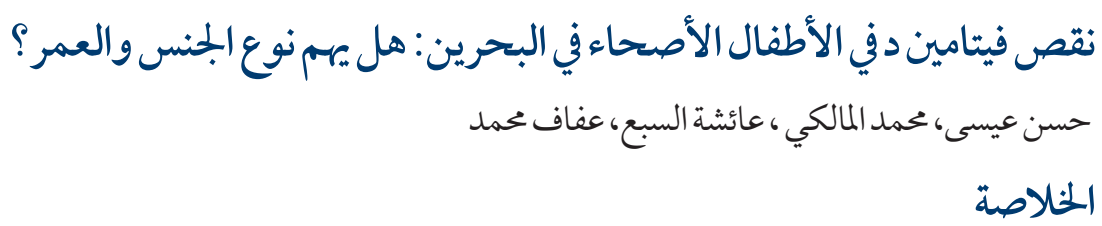

الخلفية: يُعتبر نقص فيتامين د إحدى المشاكل الصحية في الأطفال على مستوى العالم. ولمَيجرَرِمن قبل في البحرين تقييمّ لحالة فيتامين دفي الأطفال والمر اهقين. الأهداف: هدفت الدراسة التي شملت عدة قطاعات إلى تحديد انتشار نقص فيتامين د في الأطفال الأصحاء في البحرين و التحقيق في العلاقة بين مستوى فيتامين دو العمر ونوع الجنس. هدفت.

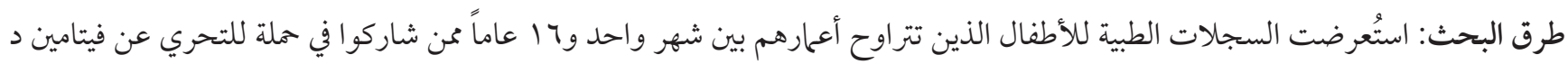

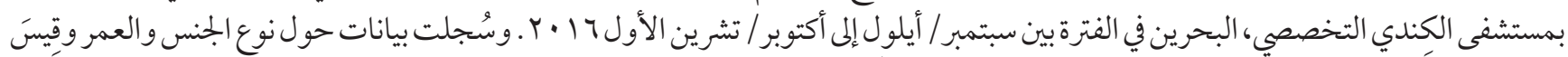

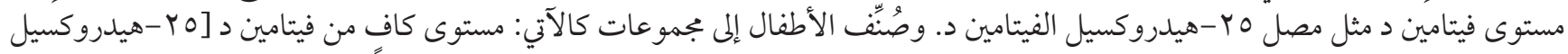

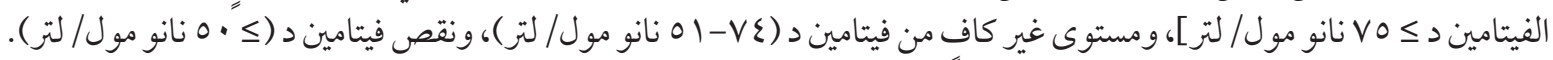

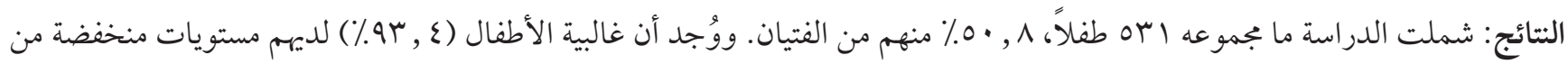

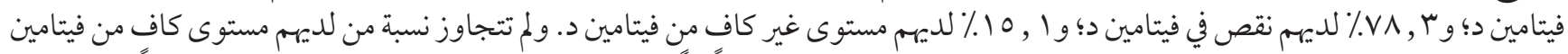

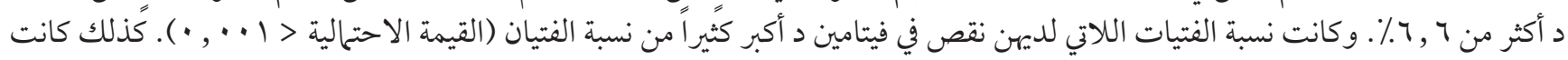

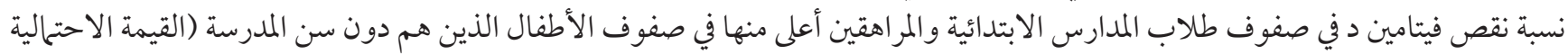

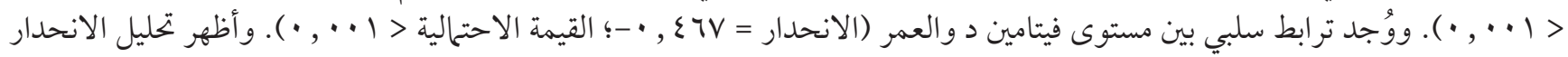

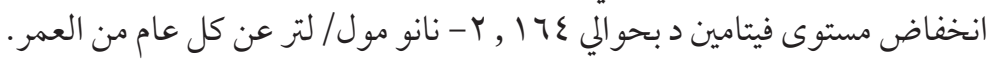

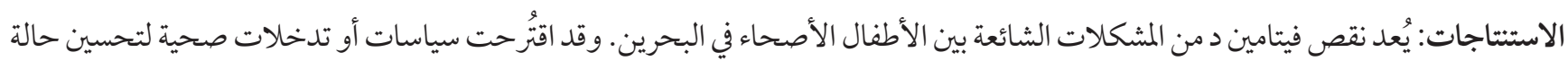
فيتامين د في البحرين، خاصة للأطفال في سن فين المدرسة. 


\section{References}

1. Al Shaikh AM, Abaalkhail B, Soliman A, Kaddam I, Aseri K, Al Saleh Y, et al. Prevalence of vitamin D deficiency and calcium homeostasis in Saudi children. J Clin Res Pediatr Endocrinol. 2016;8(4):461-7. https://doi.org/10.4274/jcrpe.3301

2. Ward LM, Gaboury I, Ladhani M, Zlotkin S. Vitamin D-deficiency rickets among children in Canada. CMAJ. 2007;177(2):161-6. https:// doi.org/10.1503/cmaj.061377

3. Flores M, Macias N, Lozada A, Sánchez LM, Díaz E, Barquera S. Serum 25-hydroxyvitamin D levels among Mexican children ages 2 y to 12 y: a national survey. Nutrition. 2013;29(5):802-4. https://doi.org/10.1016/j.nut.2012.12.024

4. Erol M, Yiğit Ö, Küçük SH, Gayret ÖB. Vitamin D deficiency in children and adolescents in Bağcllar, İstanbul. J Clin Res Pediatr Endocrinol. 2015;7(2):134-9. https://doi.org/10.4274/jcrpe.188 8

5. Munns CF, Simm PJ, Rodda CP, Garnett SP, Zacharin MR, Ward LM, et al. Incidence of vitamin D deficiency rickets among Australian children: an Australian paediatric surveillance unit study. Med J Aust. 2012;196(7):466-8. https://doi.org/10.5694/mja11.10662

6. Roh YE, Kim BR, Choi WB, Kim YM, Cho MJ, Kim HY, et al. Vitamin D deficiency in children aged 6 to 12 years: single center's experience in Busan. Ann Pediatr Endocrinol Metab. 2016;21(3):149-54. https://doi.org/10.6065/apem.2016.21.3.149

7. Saki F, Dabbaghmanesh MH, Omrani GR, Bakhshayeshkaram M. Vitamin D deficiency and its associated risk factors in children and adolescents in southern Iran. Public Health Nutr. 2015;20(10):1851-6. https://doi.org/10.1017/s1368980015001925

8. Andıran N, Çelik N, Akça H, Doğan G. Vitamin D deficiency in children and adolescents. J Clin Res Pediatr Endocrinol. 2012;4(1):25-9. https://doi.org/10.4274/jcrpe.574

9. Voortman T, van den Hooven EH, Heijboer AC, Hofman A, Jaddoe VW, Franco OH. Vitamin D deficiency in school-age children is associated with sociodemographic and lifestyle factors. J Nutr. 2015;145(4):791-8. https://doi.org/10.3945/jn.114.208280

10. Whiting SJ, Langlois KA, Vatanparast H, Greene-Finestone LS. The vitamin D status of Canadians relative to the 2011 Dietary Reference Intakes: an examination in children and adults with and without supplement use. Am J Clin Nutr. 2011;94(1):128-35. https://doi. org/10.3945/ajcn.111.013268

11. Muhairi SJ, Mehairi AE, Khouri AA, Naqbi MM, Maskari FA, Kaabi J, et al. Vitamin D deficiency among healthy adolescents in Al Ain, United Arab Emirates. BMC Public Health. 2013;13:33. https://doi.org/10.1186/1471-2458-13-33

12. Al-Mahroos FT, Al-Sahlawi HS, Al-Amer E, Mahmood NA, Sandhu AK, Sharida H, et al. Prevalence and risk factors for vitamin D deficiency among mothers in labor and their newborns. Bahrain Med Bull. 2013;35(2):60-5.

13. Golbahar J, Al-Saffar N, Diab DA, Al-Othman S, Darwish A. Vitamin D status in adults: a cross sectional study. Bahrain Med Bull. 2013;35(1):17-22.

14. Holick MF. Vitamin D status: measurement, interpretation, and clinical application. Ann Epidemiol. 2009;19(2):73-8. https://doi. org/10.1016/j.annepidem.2007

15. Souberbielle JC, Body JJ, Lappe JM, Plebani M, Shoenfeld Y, Wang TJ, et al. Vitamin D and musculoskeletal health, cardiovascular disease, autoimmunity and cancer: Recommendations for clinical practice. Autoimmun Rev. 2010;9(11):709-15. https://doi.org/10.1016/j. autrev.2010.06.009

16. Rasoul MA, Al-Mahdi M, Al-Kandari H, Dhaunsi GS, Haider MZ. Low serum vitamin-D status is associated with high prevalence and early onset of type-1 diabetes mellitus in Kuwaiti children. BMC Pediatr. 2016;16:95. https://doi.org/10.1186/s12887-016062 93

17. Al-Ghannami SS, Sedlak E, Hussein IS, Min Y, Al-Shmmkhi SM, Al-Qufi HS, et al. Lipid-soluble nutrient status of healthy Omani school children before and after intervention with oily fish meal or re-esterified triacylglycerol fish oil. Nutrition. 2016;32(1):73-8. https://doi. org/10.1016/j.nut.2015.07.014.

18. Bener A, Al-Ali M, Hoffmann GF. High prevalence of vitamin D deficiency in young children in a highly sunny humid country: a global health problem. Minerva Prediatr. 2009;61(1):15-22.

19. Zhao X, Xiao J, Liao X, Cai L, Xu F, Chen D, et al. Vitamin D status among young children aged 1-3 years: a cross-sectional study in Wuxi, China. PLoS One. 2015;10(10):e0141595. https://doi.org/10.1371/journal.pone.0141595

20. Zhu Z, Zhan J, Shao J, Chen W, Chen L, Li W, et al. High prevalence of vitamin D deficiency among children aged 1 month to 16 years in Hangzhou, China. BMC Public Health. 2012;12:126. https://doi.org/10.1186/1471-2458-12-126

21. Gordon CM, Feldman HA, Sinclair L, Williams AL, Kleinman P, Perez-Rossello J, et al. Prevalence of vitamin D deficiency among healthy infants and toddlers. Arch Pediatr Adolesc Med. 2008;162(6):505-12. https://doi.org/10.1001/archpedi.162.6.505

22. Cashman KD, Dowling KG, Skrabáková Z, Gonzalez-Gross M, Valtueña J, De Henauw S, et al. Vitamin D deficiency in Europe: pandemic? Am J Clin Nutr. 2016;103(4):1033-44. https://doi.org/10.3945/ajcn.1151.120873

23. Fuleihan GE. Vitamin D deficiency in the Middle East and its health consequences for children and adults. Clinic Rev Bone Miner Metab. 2009;7(1):77-93. https://doi.org/10.1007/s12018-009-9027-9

24. Misra M, Pacaud D, Petryk A, Collett-Solberg PF, Kappy M, Drug and Therapeutics Committee of the Lawson Wilkins Pediatric Endocrine Society. Vitamin D deficiency in children and its management: review of current knowledge and recommendations. Pediatrics 2008;122(2):398-417. https://doi.org/10.4274/jcrpe.1888 